\title{
Highly Selective and Green Oxidation of Sulfides with Urea Hydrogen Peroxide in the Presence of Mn(III) Porphyrin Supported onto Carbon Nanotubes
}

\author{
Saeed Rayati, ${ }^{@}$ and Elahe Kalhor Chegini \\ Department of Chemistry, K.N. Toosi University of Technology, Tehran, P.O. Box 16315-1618, Iran \\ ${ }^{\circledR}$ Corresponding authorE-mail: rayati@kntu.ac.ir,srayati@yahoo.com
}

\begin{abstract}
Highly selective and efficient oxidation of sulfides with an eco-friendly oxidant (urea hydrogen peroxide (UHP)) in the presence of meso-terakis(4-hydroxyphenyl)porphyrinatomanganese(III) acetate supported on multi-wall carbon nanotubes(MnTHPPOAc@MWCNT) at room temperature in ethanol has been investigated. $91 \%$ conversion for methyl phenyl sulfide with $100 \%$ selectivity for sulfoxide was obtained after 30 minute at room temperature. The effect of the different reaction conditions such as reaction time, solvent, acetic anhydride (as oxidant activator) amount of oxidant and co-catalyst on the oxidation of methyl phenyl sulfide was studied. The recycled catalysts keep constant of conversion yield up to five cycles.
\end{abstract}

Keywords: Porphyrin, manganese, catalyst, oxidation, sulfide, nanotube.

\section{Высокоселективное «зеленое» окисление сульфидов гидроперитом в присутствии Мn(III) порфирина, нанесенного на углеродные нанотрубки}

\author{
C. Райяти, ${ }^{\circledR}$ Е. К. Чегини
}

Химический факультет, Технологический университет им. К.Н. Туси, Тегеран, а/я 16315-1618, Иран

@E-mail: rayati@kntu.ac.ir,srayati@yahoo.com

\begin{abstract}
Исследована реакиия высокоселективного эффективного окисления сульфидов экологичным окислителем (гидроперитом (UHP)) в присутствии мезо-тетракис(4-гидроксифенил)порфиринатомарганец(III) ацетата, нанесенного на многостенные углеродные нанотрубки (МпTHPPOAc@MWCNT), при комнатной температуре в этаноле. Для метилфенилсульфида степень конверсии достигала $91 \%$ со 100 \% селективностью по отношению к сульфоксиду через 30 мин от начала реакиии. Было изучено влияние различных условий, таких как время реакции, природа растворителя, количество уксусного ангидрида (как активатора окисления), на окисление метилфенил сульфида. Рециклизация катализаторов составляет до пяти цииклов.
\end{abstract}

Ключевые слова: Порфирин, марганец, катализатор, окисление, сульфид, нанотрубки. 


\section{Introduction}

A great deal of attention has been focused on sulfoxides through their helpful biological and pharmacodynamics properties, serious roles in synthetic organic chemistry and important bioactive compounds. ${ }^{[1-2]}$ Therefore, catalytic oxidation of sulfides to sulfoxides has been extensively studied. ${ }^{[3-5]}$

Recently, metalloporphyrins as models of hemes or cytochrome P-450 have gained considerable attention due to their catalytic activity for monooxygenation action by formation of a high valent metal-oxo complex intermediate. ${ }^{[6-10]}$ On the other hand, homogeneous processes have some problems such as separation, recovery and disposal of spent catalysts, thus are not affordable and their uses are greatly limited. The use of heterogeneous catalysts could solve some of these difficulties. ${ }^{[1-14]}$ One of the most attractive supports to immobilize catalysts are CNTs that have been used in lots of applications such as, nano sensors for gas sensing and gas adsorption ${ }^{[15]}$ biological and medical chemistry ${ }^{[16]}$ and oxidation of olefins ${ }^{[17,18]}$ and oxidation of sulfides with numerous oxidants such as $\mathrm{PhIO}$, TBHP, $\mathrm{H}_{2} \mathrm{O}_{2}$, TBAP and UHP. ${ }^{[1,3,19-22]}$

In the present research the oxidation of sulfides catalyzed by a manganese porphyrin supported on carbon nanotubes (MnTHPPOAc@MWCNT) has been investigated. Also approach to green chemistry is located in the target too.

\section{Experimental}

Gas chromatography (GC) analyses were conducted on a Shimadzu chromatograph (model GC-14B) equipped with flame ionization detector (FID) and capillary column SAB-5 (phenyl methyl siloxane $30 \mathrm{~m} \times 320 \mathrm{~mm} \times 0.25 \mathrm{~mm}$ ). In the GC experiments, $n$-octane was used as an internal standard. The reactions were irradiated with ultrasound 296 W (WUC-A03H, DAIHAN). Chemicals were purchased from Merck or Fluka chemical companies. meso-Tetrakis(4-hydroxyphenyl)porphyrin ( $\left.\mathrm{H}_{2} \mathrm{THPP}\right)$, and meso-tetrakis(4-hydroxyphenyl)porphyrinatomanganese(III) acetate (MnTHPPOAc) were prepared according to the literature. ${ }^{[23,24]}$ MnTHPPOAc has been supported on the functionalized multi-wall carbon nanotubes (MnTHPPOAc@ MWCNT) according to the reported procedure. ${ }^{[14,25]}$

General heterogeneous oxidation procedure. Catalytic performance of MnTHPPOAc@MWCNT was carried out in a $5 \mathrm{~mL}$ test tube consist of $1 \mathrm{~mL}$ of ethanol, $0.06 \mathrm{mmol}$ of methylphenyl sulfide, $0.003 \mathrm{mmol}$ of catalyst, $0.06 \mathrm{mmol}$ of imidazole, $0.24 \mathrm{mmol}$ of UHP and $0.24 \mathrm{mmol}$ of acetic anhydride as a specific reaction. The reaction mixture was stirred for 30 minutes at room temperature. Finally the reaction products were monitored by means of gas chromatography. The sulfide oxidation products were measured by comparison with valid samples (retention times in GC).

Catalyst reuse and stability. Reusability of the heterogeneous catalyst was investigated in the numerous consecutive oxidation reactions. At the end of each reaction, the catalyst was detached from the catalytic solution by simple filtration. After isolation, the solid catalyst was washed with ethanol, separated from the solvent and dried in the air before using in the next run.

\section{Results and Discussion}

\section{Characterization of the Catalyst, MnTHPPOAc@MWCNT}

The preparation path for the MnTHPPOAc@MWCNT is shown in Scheme 1. The covalent bonding between the
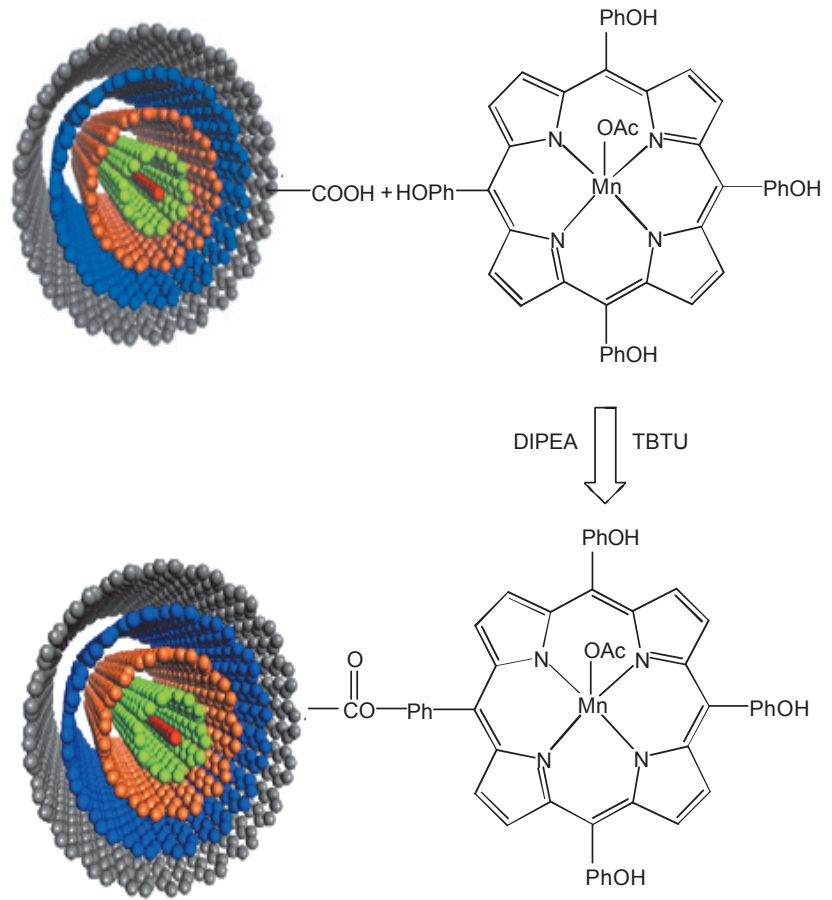

Scheme 1. Preparation path of MnTHPPOAc@MWCNT.

metalloporphyrin and MWCNT-COOH was carried out by acid-base reaction between the porphyrin hydroxyl groups and carboxcylic acid of MWCNT-COOH using 2-(1H-benzotriazole-1-yl)-1,1,3,3-tetramethyluronium tetrafluoroborate (TBTU) as a highly effective uronium salt in the presence of $N, N^{\prime}$-diisopropylamine (DIPEA). ${ }^{[25]}$

The prepared catalyst was characterized by elemental analysis, FT-IR spectroscopy and scanning electron microscopy (SEM). ${ }^{[14]}$ The nitrogen content of the catalyst was determined by $\mathrm{CHN}$ analysis, which showed a value of $0.8 \%$ for the Mn-catalyst. Based on this value, the manganese porphyrin content of the catalyst obtained was about $357 \mu \mathrm{mol}$ per gram of the catalyst. The Mn content of the catalyst was also measured by atomic absorption spectroscopy, and this was comparable to data obtained by CHN analysis. In the FT-IR spectra, a sharp band observed at $1714 \mathrm{~cm}^{-1}$ is related to the esteric bond formed between carboxylic acid groups of the carbon nanotubes and $\mathrm{OH}$ groups of the Mn-porphyrin. Also, SEM image of the catalyst shows the morphology and shape of the supported nanotubes (Figure 1).

\section{Catalytic Oxidation of Methyl Phenyl Sulfide}

The catalytic activity of the heterogeneous catalyst was investigated on the oxidation of methyl phenyl sulfide with UHP and acetic anhydride as an activator (Scheme 2). A series of blank experiments revealed that the presence of catalyst, oxidant and activator are essential for an effective catalytic reaction (Table 1). In order to increase the conversion, the effect of different parameters was studied.

Effect of acetic anhydride. In the absence of an oxidant activator, the reaction does not proceed, while in the presence of acetic anhydride $17 \%$ methyl phenyl sulfoxide was obtained. In order to find the optimum amount of acetic 


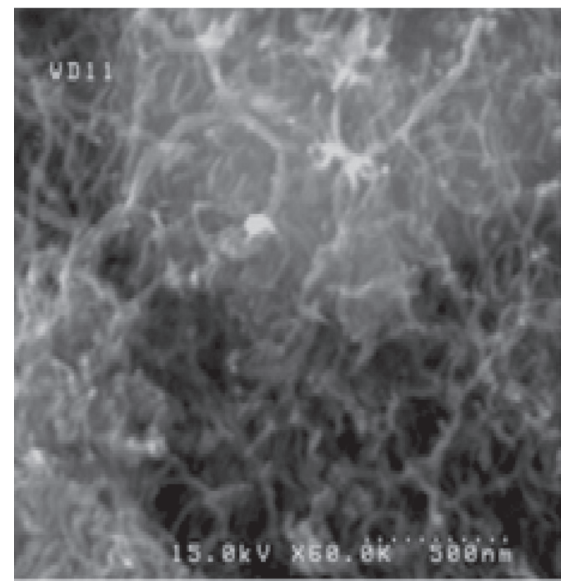

Figure 1. SEM image of the MnTHPPOAc@MWCNT.

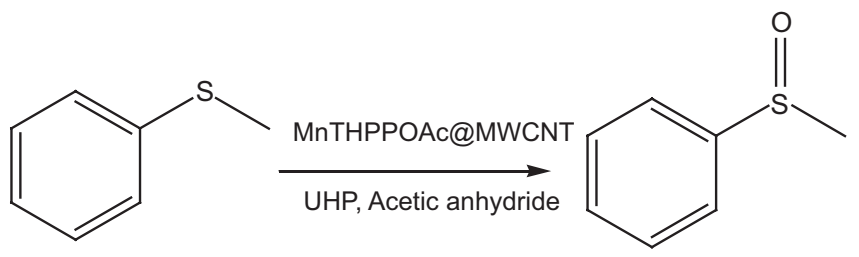

Scheme 2. Oxidation of methyl phenyl sulfide.

Table 1. Blank experiments on catalytic activity of methyl phenyl sulfide at room temperature. ${ }^{\mathrm{a}}$

\begin{tabular}{ccccc}
\hline No. & Catalyst & Oxidant & Activator & Conversion, \% \\
\hline 1 & none & UHP & none & 0 \\
2 & $\begin{array}{c}\text { MnTHPPOAc@ } \\
\text { MWCNT }\end{array}$ & none & none & 0 \\
3 & none & UHP & $\begin{array}{c}\text { Acetic } \\
\text { anhydride }\end{array}$ & 22 \\
\hline
\end{tabular}

aReaction conditions: the molar ratio for Catalyst: ImH: Sulfide: UHP: Acetic anhydride is (1:30:20:80:80). Reaction time: 30 minutes.

anhydride on the oxidation of methyl phenyl sulfide, different amounts of acetic anhydride were used and 1:1 molar ratio was chosen to be used on the oxidation of methyl phenyl sulfide (Table 2).

Table 2. The effect of acetic anhydride amounts on the oxidation of methyl phenyl sulfide catalyzed by [Mn(THPP)OAc@MWCNT] with UHP in $\mathrm{CH}_{2} \mathrm{Cl}_{2}: \mathrm{MeOH}(9: 1)$ at room temperature. ${ }^{\mathrm{a}, \mathrm{b}}$

\begin{tabular}{ccc}
\hline $\begin{array}{c}\text { Acetic } \\
\text { anhydride/UHP }\end{array}$ & $\begin{array}{c}\text { Conversion, } \\
\%\end{array}$ & Selectivity, \% (sulfoxide) \\
\hline 0 & 0 & 0 \\
0.5 & 11 & 100 \\
0.75 & 13 & 100 \\
1 & 17 & 100 \\
\hline
\end{tabular}

aReaction conditions: the molar ratio for Catalyst: ImH: Sulfide: UHP are (1:30:20:60:X);

${ }^{\mathrm{b}}$ Reaction time: 30 minutes.
Solvent effect. In order to find an appropriate solvent for the oxidation of methyl phenyl sulfide with UHP, different solvents such as methanol, ethanol and the mixture of $\mathrm{MeOH}: \mathrm{CH}_{2} \mathrm{Cl}_{2}$ were applied (Table 3) and among them, ethanol showed the highest conversion for the oxidation of methyl phenyl sulfide.

Table 3. Solvent effect on the oxidation of methyl phenyl sulfide catalyzed by [Mn(THPP)OAc@MWCNT] with UHP at room temperature. ${ }^{\mathrm{a}, \mathrm{b}}$

\begin{tabular}{ccc}
\hline Solvent & Conversion, \% & Selectivity, \% (sulfoxide) \\
\hline $\mathrm{CH}_{2} \mathrm{Cl}_{2}: \mathrm{MeOH}(9: 1)$ & 17 & 100 \\
$\mathrm{CH}_{2} \mathrm{Cl}_{2}: \mathrm{MeOH}(1: 1)$ & 25 & 100 \\
$\mathrm{MeOH}$ & 37 & 100 \\
$\mathrm{EtOH}$ & 49 & 100 \\
\hline
\end{tabular}

a Reaction conditions: the molar ratio for Catalyst: ImH: Sulfide: UHP: Acetic anhydride is (1:30:20:60:60);

bReaction time: 30 minutes.

The effect of UHP concentration. The effect of different amounts of oxidant has been examined and the results were summarized in Table 4.The results indicate that maximum conversion was obtained at 4:1 molar ratio of UHP to sulfide.

Table 4. Optimization of the oxidant amounts on the oxidation of methyl phenyl sulfide with UHP in ethanol at room temperature. ${ }^{\mathrm{a}, \mathrm{b}}$

\begin{tabular}{cccc}
\hline Entry & UHP/Sulfide & Conversion, \% & Selectivity, \% (sulfoxide) \\
\hline 1 & 3 & 49 & 100 \\
2 & 4 & 58 & 100 \\
\hline
\end{tabular}

a Reaction conditions: the molar ratio for Catalyst: ImH: Sulfide: UHP: Acetic anhydride is (1:30:20:X:X);

${ }^{\mathrm{b}}$ Reaction time: 30 minutes.

Optimization of imidazole molar ratios. Since the catalytic activity of metalloporphyrins increase in the presence of imidazole as co-catalyst, the effect of different molar ratios of imidazole/catalyst on the oxidation of methyl phenyl sulfide, has been investigated (Figure 2). The highest conversion was achieved in the 1:20 molar ratio of the catalyst to imidazole. In the absence of imidazole, oxidation proceeds only in $27 \%$. Surplus of imidazole led to a decrease in the conversion that might be due to the formation of the inactive six coordinated species.

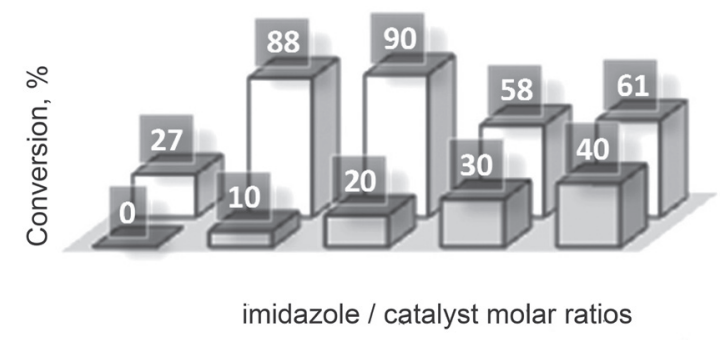

Figure 2. Influence of imidazole/catalyst molar ratios on the oxidation of methyl phenyl sulfide with UHP in ethanol at room temperature. Reaction conditions: the molar ratio for Catalyst: ImH:Sulfide:UHP:Acetic anhydride is $(1: X: 20: 80: 80)$. Reaction time: 30 minutes. 
Optimization of the catalyst amount. In order to optimize the concentration of the catalyst in the oxidation of methyl phenyl sulfide with UHP, different amounts of catalyst were used. A blank assay revealed that the presence of a catalyst is vital for a typical reaction. In the absence of catalyst, the reaction carried out only $22 \%$. The highest conversion was obtained with $0.003 \mathrm{mmol}(6.4 \mathrm{mg})$ of the catalyst (Figure 3).

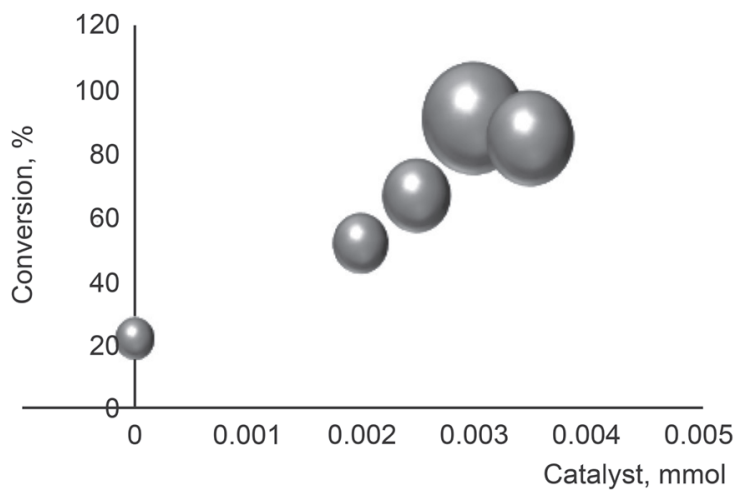

Figure 3. Optimization of catalyst amounts on the oxidation of methyl phenyl sulfide with UHP in ethanol at room temperature. Reaction conditions: the molar ratio for Catalyst:ImH:Sulfide:UHP: Acetic anhydride is (1:20:20:80:80). Reaction time: 30 minutes.

Optimization of reaction time. In order to find a desired reaction time for the oxidation of methyl phenyl sulfide, several reaction times were investigated (Figure 4). Although a 40 minute reaction showed high conversion yield, but increase of the conversion was not significant. So a 30 minute reaction was selected to save time.

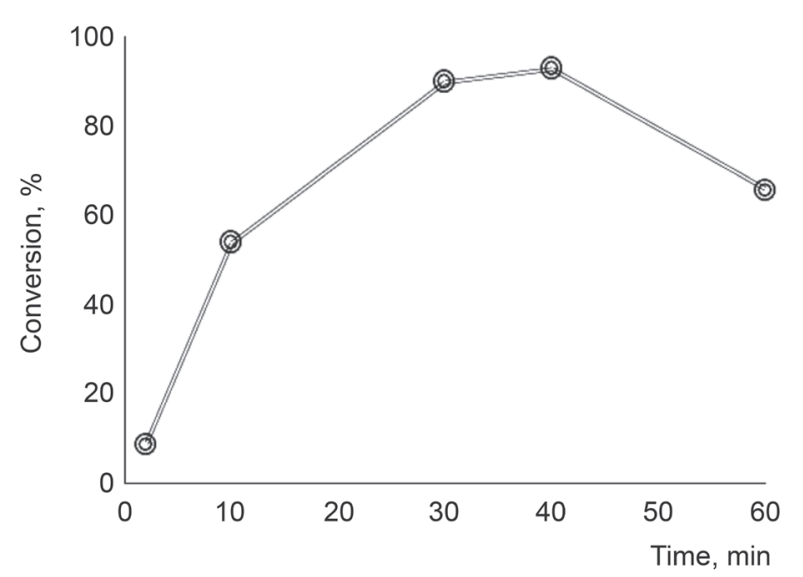

Figure 4. Optimization of reaction time on the oxidation of methyl phenyl sulfide catalyzed by [Mn(THPP)OAc@MWCNT] with UHP in ethanol at room temperature. Reaction conditions: the molar ratio for Catalyst: ImH:Sulfide:UHP:Acetic anhydride is $(1: 20: 20: 80: 80)$.

Effect of ultrasonic irradiation. Alternatively, the effect of ultrasonic irradiation on the oxidation of methyl phenyl sulfide has been studied (Table 5). In a similar condition, a 30 minute reaction under magnetic stirring can be carried out
Table 5. Oxidation of methyl phenyl sulfide catalyzed by [Mn(THPP)OAc@MWCNT] with UHPin ethanol under ultrasonic irradiation at room temperature. ${ }^{\mathrm{a}}$

\begin{tabular}{ccc}
\hline Time, $\min$ & Conversion, $\%$ & Selectivity, \% (sulfoxide) \\
\hline 7 & 63 & 100 \\
15 & 89 & 100 \\
\hline
\end{tabular}

a Reaction conditions: the molar ratio for Catalyst:ImH:Sulfide: UHP:Acetic anhydride is $(1: 20: 20: 80: 80)$.

in 15 minutes using ultrasonic irradiation with resembling conversion as well (or 15 minute reaction under ultrasonic irradiation can carry out as well as a 30 minute reaction under similar conditions).

\section{Oxidation of Various Sulfides with UHP Catalyzed by [Mn(THPP)OAc@MWCNT]}

In order to demonstrate the efficiency of this heterogeneous catalytic system, oxidation of other sulfides under optimized conditions have also been carried out. As results shown in Table 6 , sulfides are effectively oxidized to corresponding sulfoxides as sole products.

Table 6. Oxidation of various sulfides catalyzed by [Mn(THPP) OAc@MWCNT] with UHP in ethanol at room temperature. ${ }^{\mathrm{a}, \mathrm{b}}$

\begin{tabular}{|c|c|c|}
\hline Time, $\min$ & Conversion, $\%$ & Selectivity, \% (sulfoxide) \\
\hline $\mathrm{CH}_{3}$ & 91 & 100 \\
\hline & 100 & 100 \\
\hline & 100 & 100 \\
\hline & 100 & 100 \\
\hline
\end{tabular}

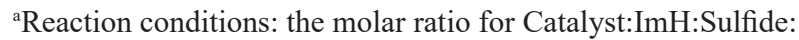
UHP: Acetic anhydride is (1:20:20:80:80);

${ }^{\mathrm{b}}$ Reaction time: 30 minutes.

\section{Proposed Catalytic Mechanism}

In the absence of catalyst, $22 \%$ conversion for methyl phenyl sulfide was obtained. This observation suggests that the formed peracetic (Scheme 3, I) from reaction of urea hydrogen peroxide and acetic anhydride can oxidize the sulfide to sulfoxide. The rest of $69 \%$ of $91 \%$ conversion is probably due to the catalytic oxidation of sulfide to sulfoxide. It is possible that peracetic acid coordinates to the manganese of [Mn(THPP)OAc@MWCNT] to form a six coordinated species (Scheme 3, I). The six coordinated species may transfer an oxygen atom to sulfide to form sulfoxide product.

\section{Catalyst Reuse and Stability}

One of the most important properties of a heterogeneous catalyst is their reusability. In this work, catalysts were 


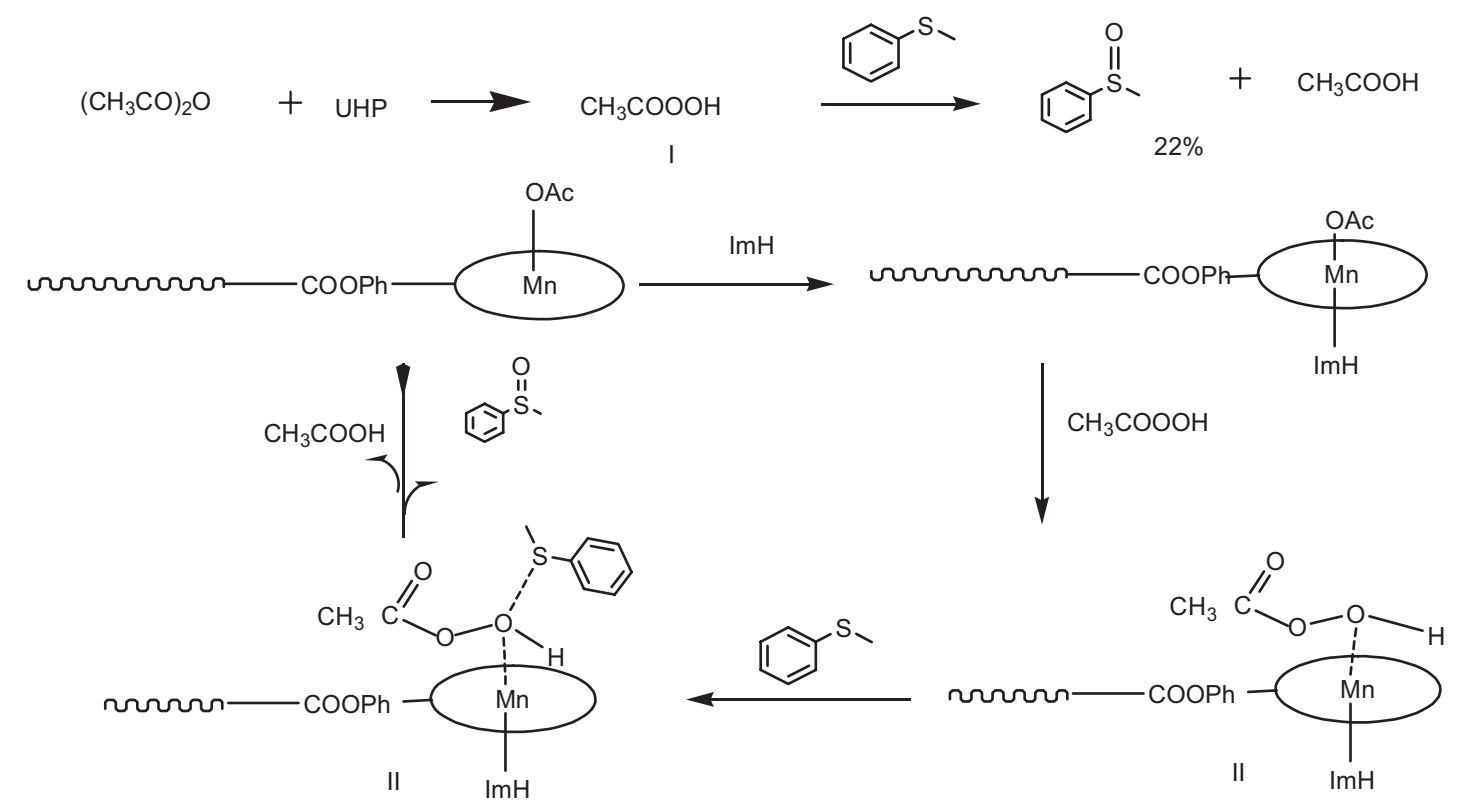

Scheme 3. Proposed catalytic cycle.

reused successively for five times under the same reaction condition. The catalyst was separated from the reaction mixture after each experiment by simple filtration or centrifugation, washed with ethanol (three times) and dried before using in the next run. After reuse of each catalyst the sulfoxide yields were $100 \%$.

\section{Conclusions}

Summery, MnTHPPOAc anchored on CNTs, has been employed on the oxidation of sulfides with UHP as a green oxidant under mild conditions. High selectivity and efficiency are advantages of this catalytic system. It should be mentioned that this system has advantages included mild conditions, high conversion yield, recyclable catalyst and chemo selective oxidation of methyl phenyl sulfide.

Acknowledgements. The support of this work by K.N. Toosi University of Technology research council is appreciated.

\section{References}

1. Fuerte A., Iglesias M., Sanchez F., Corma A. J. Mol. Catal. A Chem. 2004, 211, 227-235.

2. Bagherzadeh M., Amini M. Inorg. Chem. Commun. 2009, 12, 21-25.

3. Rayati S., Nejabat F., Zakavi S. Inorg. Chem. Commun. 2014, 40, 82-86.

4. Ghaemi A., Rayati S., Zakavi S., Safari N. Appl. Catal., A 2009, 353, 154-159.

5. Rayati S., Zakavi S., Noroozi V. J. Sulfur Chem. 2010, 31, 89-95.

6. Srour H., Jalkh J., Maux P.L., Chevance S., Kobeissi M., Simonneaux G. J. Mol. Catal. A: Chem. 2013, 370, 75-79.
7. Sansiaume E., Ricoux R., Gori D., Mahy J. Tetrahedron: Asymmetry 2010, 21, 1593-1600.

8. Rezaeifard A., Jafarpour M., Raissi H., Ghiamati E., Tootoonchi A. Polyhedron 2011, 30, 592-598.

9. Rayati S., Zakavi S., Bohloulbandi E., Jafarian M., Rashvandavei M. Polyhedron 2012, 34, 102-107.

10. Rayati S., Zakavi S., Motlagh S. H., Noroozi V., Razmjoo M., Wojtczak A., Kozakiewicz A. Polyhedron 2008, 27, 22852290.

11. Li Z., Xue L., Wang L., Zhang S., Zhao B. Inorg. Chem. Commun. 2013, 27, 119-122.

12. Rayati S., Bohloulbandi E. Compt. Rend. Chim. 2014, 17, 62-68.

13. Rayati S., Abdolalian P. Compt. Rend. Chim. 2013, 16, 814820.

14. Rayati S., Jafarzadeh P., Zakavi S. Inorg. Chem. Commun. 2013, 29, 40-44.

15. Penza M., Rossi R., Alvisi M., Signore M.A., Serra E., Paolesse R., D’Amico A., Dinatale C. Sens. Actuators, B 2010 , 144, 387-394.

16. Kam N.W.S., Jessop T.C., Wender P.A., Dai H.J. J. Am. Chem. Soc. 2004, 126, 6850-6851.

17. Rayati S., Jafarzadeh P., Zakavi S. Inorg. Chem. Commun. 2013, 29, 40-44.

18. Rayati S., Abdolalian P. Appl. Catal., A 2013, 456, 240-248.

19. Ferrand Y., Daviaud R., Maux P.L., Simonneaux G. Tetrahedron: Asymmetry 2006, 17, 952-960.

20. Palombi L., Bocchino C., Caruso T., Villano R., Scettri A. Tetrahedron Lett. 2008, 49, 5611-5614.

21. Sheikhshoaie I., Rezaeifard A., Monadi N., Kaafi S. Polyhedron 2009, 28, 733-738.

22. Najafpour M.M., Hołyn'ska M., Shamkhali A.N., Amini M., Kazemi S.H., Zaynalpoor S., Mohamadi R., Bagherzadeh M., Lis T. Polyhedron 2012, 34, 202-209.

23. Adler A.D., Longo F.R., Shergalis W. J. Am. Chem. Soc. 1964, 86, 3145-3149.

24. Buchler J.W., Eikellmann G., Puppe J., Rohback K., Schneehage H., Weck D. Liebigs, Ann. Chem. 1971, 745, 135-151.

25. Balalaie S., Mahdidust M., Najafabadi R.E. Chin. J. Chem. 2008, 26, 1141-1144. 